\title{
Synthesis of C-glycosides from 1,6-Diamino-4-Phenylpyridine Derivatives
}

\author{
Atef M.Amer, Amira A. Ghoneim*, Mohamed H. Sherif, Wael Farouk \\ Chemistry Department, Faculty of Science, Zagazig University, Zagazig, Egypt \\ *Corresponding Author: aaghonium@yzu.edu.eg
}

Copyright $@ 2014$ Horizon Research Publishing All rights reserved.

\begin{abstract}
Diamino $3 \mathrm{a}$ and $3 \mathrm{~b}$ derivatives which obtained by Michael reaction were coupled with aldoses in the presence of acetic acid and $\mathrm{I}_{2}$ with stirring at room temperature gave 4, 5 and 6 respectively. Acetylation of compound 4 and 5 gave compound 7 and 8 respectively. Coupling of fructose with $3 \mathrm{a}$ and $3 \mathrm{~b}$ in the presence or not of Con $\mathrm{HCl}$ gave compound 9 and 11 respectively. Acetylation of compound 9 with acetic anhydride and Pyridine gave compound 10. Some of the synthesized compounds have been screened as antibacterial and antifungal. The structures of the synthesized compounds have been deduced from their elemental analysis and spectral (IR, 1H-NMR) data.
\end{abstract}

Keywords C-glycosides, Cyanoacetohydrazide, Arylidinemalononitrile

\section{Introduction}

C-glycosides, wherein a carbon atom replaces the glycosidic oxygen have attracted considerable attention in carbohydrate and biological chemistry because of their stability [1] towards enzymatic acidic hydrolysis. In particular hexapyranosyl nucleosides as well as Cglycoconjugates bearing carbon linked nitrogen heterocycles have given rise to numerous synthetic and biological studies [2], due to their potential antiviral and antitumor activities. Various approaches to C-glycosides have been developed [3-5]. The reaction of C-centered nucleophiles with an activated and electrophilic C-glycosyl donor or glycal represents by far the most common approach, although anomeric nucleophiles [6] and radical have also been used to generate such compounds.

Generally C- glycosyl heteroaromatics were prepared from glycosyl donors such as glycosyl halides [7], hydroxides or O-glycosyl trichloroacetimidates using either the hetero aryl compounds in presence of lewis acids $[8,9]$.

\section{Experimental}

\subsection{Instrumentation}

All reagents and solvents were purified either by recrystallization or distillation, unless otherwise. Thin layer chromatography was carried out using indicating silica gel. Infrared spectra were recorded as potassium bromide discs on a Perkin-Elmer 383 spectrometer. ${ }^{1} \mathrm{H}$ NMR spectra were obtained on a Brucker AC 200F instrumental at r.t in the solvent indicated chemical shifts are reported in pmm from TMS as the internal standard. The type of signals was indicated by the following letters. Also ${ }^{1} \mathrm{HNMR}$ spectra were measured on a Varian spectrophotometer at $300 \mathrm{MHz}$ using DMSO-d6 or $\mathrm{CDCl}_{3}$ as solvent at chemistry department faculty of science, Bardouex University-France. Mass spectra were determined at 70 or 15 electron volt by using AE / MS 30 mass spectrometer. Analytical data were performed by the microanalytical data unit at chemistry department faculty of science, Bardouex University - France and Cairo University, Egypt. All melting points were recorded using thermal melting point apparatus and were uncorrected

\subsubsection{1,6-Diamino-2-oxo-4-phenyl-1,2-dihydropyridine-3, 5-dicarbonitrile(3a):}

A mixture of cyanoacetohydrazide (1) $(0.01 \mathrm{~mol}, 1.09 \mathrm{~g})$ and benzylidine malononitrile $(2 \mathrm{a})(0.01 \mathrm{~mol}, 1.54 \mathrm{~g})$ in ethanol $15 \mathrm{ml}$ and few drops of piperidine was refluxed for 3 hours. The solid thus formed was collected by filtration and recrystallized from methanol gave $3 \mathrm{a}$ as a pale yellow powder in $80 \%$ yield, m.p. $260-262^{\circ} \mathrm{C}$. The ${ }^{1} \mathrm{H}-\mathrm{NMR}$ $\left(\mathrm{DMSO}_{6} \mathrm{~d}_{6} \delta: 5.66\left(\mathrm{~s}, 2 \mathrm{H}, \mathrm{NH}_{2}\right), 7.49\left(\mathrm{~s}, 2 \mathrm{H}, 2 \mathrm{H}_{\mathrm{ar}}\right.\right.$ ) $), 7.54(\mathrm{~s}$, $3 \mathrm{H}, 3 \mathrm{Har}$.) and $8.48\left(\mathrm{~s}, 2 \mathrm{H}, \mathrm{NH}_{2}\right) \mathrm{ppm}$. Anal. Calcd for $\left(\mathrm{C}_{13} \mathrm{H}_{9} \mathrm{~N}_{5} \mathrm{O}\right.$,

M. W.: 251.24): C, 62.15; H, 3.61; N, 27.87. Found: C, $61.98 ; \mathrm{H}, 3.53 ; \mathrm{N}, 27.53$

\subsection{2.}

1,6-Diamino-4-(1,3-diphenyl-1H-pyrazol-4-yl)-2-oxo -1,2-dihydropyridi-ne-3,5-dicarbonitrile (3b):

A mixture of cyanoacetohydrazide (1) $(0.01 \mathrm{~mol}, 1.09 \mathrm{~g})$ and pyrazolidine malononitrile (2b) $(0.01 \mathrm{~mol}, 2.96 \mathrm{~g})$ in ethanol $(15 \mathrm{ml})$ and few drops of piperidine was refluxed for 
$3 \mathrm{hrs}$. The solid was formed and collected by filteration and recrystallized from methanol gave $3 \mathrm{~b}$ as a pale yellow powder in $80 \%$ yield, m.p. $240-242^{\circ} \mathrm{C} .{ }^{1} \mathrm{H}-\mathrm{NMR}\left(\mathrm{CDCl}_{3}\right) \delta$ : $4.70\left(\mathrm{~s}, 1 \mathrm{H}, \mathrm{NH}_{2}\right), 7.48\left(\mathrm{~m}, 8 \mathrm{H}, \mathrm{H}_{\mathrm{ar}}.\right), 7.80\left(\mathrm{~d}, 2 \mathrm{H}, \mathrm{H}_{\mathrm{ar}}.\right)$ and 8.26 $\left(\mathrm{s}, 1 \mathrm{H}, \mathrm{H}_{\text {pyrazole }}\right)$ ppm. Anal. Calcd for $\left(\mathrm{C}_{22} \mathrm{H}_{15} \mathrm{~N}_{7} \mathrm{O}, \mathrm{M} . \mathrm{W}\right.$. 393.40): C, 67.17; H, 3.84; N, 24.92. Found: C, 67.14; H, $3.80 ; \mathrm{N}, 24.90$.

\subsection{3.}

3,5-Dihydro-2-(D-gluco-pentitol-1-yl)-5-oxo-7-pheny $1[1,2,4]$ triazolo[1,5-a]pyridine-6,8-dicarbonitrile(4):

A solution of $3 \mathrm{a}(1 \mathrm{mmol}, 0.251 \mathrm{~g})$ and D-glucose ( $1 \mathrm{mmol}$, $0.180 \mathrm{~g}$ ) were dissolved in iodine solution ( $1 \mathrm{mmol}, 0.254 \mathrm{~g}$ ) in methanol $(2 \mathrm{ml})$ at room temperature until the D-glucose was completely consumed as indicated by the TLC .The reaction mixture was quenched by addition of $\mathrm{Na}_{2} \mathrm{~S}_{2} \mathrm{O}_{3}(2 \mathrm{ml})$ of saturated aqueous solution, and the mixture was concentrated under reduced pressure to give crude product which was washed successively with water and methanol then recrystallized from ethanol gave 4 as yellow powder ,68\% yield, m.p. $205-207^{\circ} \mathrm{C}$, I.R(KBr): $3395(\mathrm{OH}), 3236(\mathrm{NH})$, $3195(\mathrm{CH})$ aromatic bonds, $2949(\mathrm{CH})$ aliphatic bonds, 2236 $(\mathrm{C} \equiv \mathrm{N}), 1695(\mathrm{C}=\mathrm{O}$ amide $)$ and $1605,1521,1465 \mathrm{~cm}^{-1}(\mathrm{C}=\mathrm{N})$ and $(\mathrm{C}=\mathrm{C})$. MS (m/z) : 412(8\%), 411(34\%), 393(51\%), 380 (24\%), $322(20 \%), 321(34 \%), 320(44 \%), 305(22 \%)$, $304(10 \%), 292(36 \%), 290(100 \%), 275(13 \%), 274(11 \%)$, $261(11 \%), 260(42 \%), 234(34 \%)$ and $77(50 \%)$.

Anal. Calcd for $\left(\mathrm{C}_{19} \mathrm{H}_{17} \mathrm{~N}_{5} \mathrm{O}_{6}\right.$, M.W. 408.41): C, 55.47; $\mathrm{H}$, 4.17; N, 17.02. Found: C, 55.39; H, 4.21; N, 17.06.

2.1.4.

3,5-Dihydro-2-(D-xylo-pentitol-1-yl)-5-oxo-7-phenyl -[1,2,4]triazolo[1,5-a]pyridine-6,8-dicarbonitrile (5):

A mixture of (3a) (1mmol, $0.251 \mathrm{~g})$ and D-xylose were dissolved in a solution containing acetic acid $(5 \mathrm{ml})$ and water $(10 \mathrm{ml})$.The mixture was stirred with a solution of iodine ( $1 \mathrm{mmol}, 0.254)$ and by the same conditions as compound (4), the reaction was completed afforded 5 as a pale yellow powder, yield $48 \%$. m.p. $201-203^{\circ} \mathrm{C}$. IR ( $\left.\mathrm{KBr}\right)$ : $3400(\mathrm{OH})$ groups, $3232(\mathrm{NH})$ group, $3193(\mathrm{CH})$ aromatic bonds, $2925(\mathrm{CH})$ aliphatic bonds, $2225(\mathrm{C} \equiv \mathrm{N})$ groups, 1672 $(\mathrm{C}=\mathrm{O})$ amide group and $1593,1539,1427 \mathrm{~cm}^{-1}(\mathrm{C}=\mathrm{N})$ and $(\mathrm{C}=\mathrm{C}) . \mathrm{MS} \mathrm{m} / \mathrm{z}: 382(13 \%), 381(28 \%), 364(24 \%), 350$ $(13 \%), 322(17 \%), 321(10 \%), 320(27 \%), 303(19 \%), 302$ $(13 \%), 291$ (65), $289(17 \%), 288$ (6\%), 275 (24\%), $261(17 \%), 260(34 \%), 234(20 \%$, ) and 77(100\%). Anal. Calcd for

$\left(\mathrm{C}_{18} \mathrm{H}_{15} \mathrm{~N}_{5} \mathrm{O}_{5}\right.$, M.W. 408.41): C,56.69; H,3.96; N, 18.37. Found: C, 56.68; H ,3.93; N, 18.34 .

2.1.5.

2-(D-xylo-tetritol-1-yl)-5-oxo-7-(1,3-diphenyl-1H-py razol-4-yl)[1,2,4]-triazolo[1,5-a]pyridine-6,8-dicarbo nitrile(6):

A mixture of pyridone $3 \mathrm{~b}$ (1mmol, $0.393 \mathrm{~g}$ ), D-xylose $(1 \mathrm{mmol}, 0.160 \mathrm{~g})$ and iodine (1 mmol, $0.254 \mathrm{~g})$ were dissolved in DMF $(1 \mathrm{ml})$ and diluted acetic acid $(5 \mathrm{ml})$. The mixture was stirred with slight heating at $50^{\circ} \mathrm{C}$ for $10 \mathrm{hrs}$, the solvent was evaporated and the residue washed with water successively and recrystallized from methanol yielded $\mathbf{6}$ as a whitish green powder, $43 \%$ yield. m.p. $170-172^{\circ} \mathrm{C}$. IR (KBr): $3400(\mathrm{OH}), 3150(\mathrm{NH}), 3000(\mathrm{CH})$ aromatic bands, 2925 $(\mathrm{CH})$ aliphatic bands, $2236(\mathrm{C} \equiv \mathrm{N}), 1666(\mathrm{C}=\mathrm{O})$ amide group $1600,1593,1504,1410 \mathrm{~cm}^{-1}(\mathrm{C}=\mathrm{N})$ and $(\mathrm{C}=\mathrm{C})$. MS m/z: 523 (34\%), 492(10\%), 464 (60\%), 463 (76\%), 462 (50\%), 447 (11\%), 446(13\%), 445 (52\%), $433(100 \%), 432(12 \%)$, 431(13\%), 430 (36\%), 402 (10\%), 376 (9\%), 375 (45\%). Anal. Calcd for $\left(\mathrm{C}_{27} \mathrm{H}_{21} \mathrm{~N}_{7} \mathrm{O}_{5}\right.$, M.W. 523.50): C, 61.95; H, 4.04; N, 18.73. Found: C, 61.90; H, 4.02; N, 18.76.

2.1.6.

3-(N-acetyl)-3,5-dihydro-2-(1,2,3,4,5-penta-O-acetylD-gluco-pentitol-1-yl)-5-oxo-7-phenyl-[1,2,4]triazolo [1,5-a]pyridine-6,8-dicarbonitrile(7):

A suspension of 4 (2mmole, $0.822 \mathrm{~g}$ ) was boiled with acetic anhydride $(10 \mathrm{ml})$ under reflux for $3 \mathrm{hrs}$. The hot solution was poured onto crushed ice and the acetate 7 was filtered off, washed with water and recrystallized from DMF and water gave white crystals, Yield 71\%. m.p. $133-135^{\circ} \mathrm{C}$. IR $(\mathrm{KBr}): 3059(\mathrm{CH})$ aromatic bonds, $2920(\mathrm{CH})$ aliphatic bonds, $2223(\mathrm{C} \equiv \mathrm{N})$ groups, $1725(\mathrm{C}=\mathrm{O})$ ester, $1678(\mathrm{C}=\mathrm{O})$ amide and 1596, 1530, 1503, $1432 \mathrm{~cm}^{-1}(\mathrm{C}=\mathrm{N})$ and $(\mathrm{C}=\mathrm{C})$. MS m/z: 663 (56\%), 620 (38\%), 603 (12\%), 561(28\%), 549 (12\%), $543(12 \%), 530(28 \%), 501(16 \%), 488(29 \%), 387$ (17\%), 362 (16\%),345 (41\%), 332 (100\%), $316(12 \%), 302$ (28\%), $275(30 \%), 259$ (12\%), 246 (36\%), 219(12\%), 127 $(36 \%),, 77(66 \%), 50(55 \%)$. Anal. Calcd for $\left(\mathrm{C}_{31} \mathrm{H}_{29} \mathrm{~N}_{5} \mathrm{O}_{12}\right.$, M.W. 663.59): C, 56.11; H, 4.40; N, 10.55. Found: C, 56.14; $\mathrm{H}, 4.45 ; \mathrm{N}, 10.57$.

\subsection{7.}

3-(N-acetyl)-3,5-dihydro-2-(1,2,3,4-tetra-O-acetyl-Dxylo-tetritol-1-yl)-5-oxo-7-phenyl[1,2,4]triazolo[1,5a]pyridine-6,8-dicarbonitrile (8):

The same procedure was repeated as compound 7 with the same conditions compound 8 obtained as a white crystals, yield $66 \%$, m.p. $148-150^{\circ} \mathrm{C}$, MS (m/z, \%) $591(33 \%)$, 531(13\%), 489 (29\%), 471 (25\%), 458 (13\%), 429 (9\%), 416 (10\%),387 (7\%), 345 (32\%), 332 (76\%), 330 (30\%), 316 $(8 \%), 302(13 \%), 276$ (37\%), 259 (16\%), 219 (9\%), 127(19\%), 77 (100\%). Anal. Calcd for: $\left(\mathrm{C}_{28} \mathrm{H}_{25} \mathrm{~N}_{5} \mathrm{O}_{10}\right.$, M. wt. 591.53): C, 56.85; H, 4.26; N, 11.84. Found: C, 56.90; H, $4.29 ; \mathrm{N}, 11.88$

2.1.8.

3-(D-Arabino-tetritol-1-yl)-6-oxo-8-phenyl-6H-pyrid o[1,2-b][1,2,4]triazine-7,9-dicarbonitrile (9):

A catalytic amounts of concentrated $\mathrm{HCl}$ (few drops) was added to solution of pyridine $3 \mathrm{a}$

$(1 \mathrm{mmol}, 0.251 \mathrm{~g})$ and D-fructose $(1 \mathrm{mmol}, 0.180 \mathrm{~g})$ in ethanol $(20 \mathrm{ml})$, the reaction mixture was stirred under reflux for $5 \mathrm{hrs}$. The precipitate formed by cooling was filtered off and washed with distilled water successively and 
recrystallized from ethanol and water afforded 9 as a white powder, yield $67 \%$, m.p. $270-272^{\circ} \mathrm{C}$, MS (m/z \%): $394(4 \%$, M), 363 (21\%), 315(16\%), 314 (39\%), $303 \quad(19 \%)$, $302(100 \%), \quad 301(\quad 20 \%), \quad 300 \quad(27 \%), \quad 272 \quad(43 \%)$, 245(47\%),219(21\%). Anal. Calcd for: $\left(\mathrm{C}_{19} \mathrm{H}_{15} \mathrm{~N}_{5} \mathrm{O}_{5}\right.$, Mwt. 393.11): C, 58.01; H, 3.84; N, 17.80. Found: C, 58.90; H, $3.88 ; \mathrm{N}, 17.79$.

2.1.9.

3-(1,2,3,4-tetra-O-acetyl-D-arabino-1-yl)-6-oxo-8-ph enyl-6H-pyrido[1,2-b][1,2,4]

triazine-7,9-dicarbonitrile (10):

A suspension of 9 (1mmol, $0.393 \mathrm{~g})$ in $3 \mathrm{ml}$ of acetic anhydride and pyridine $3 \mathrm{ml}$ was refluxed for $3 \mathrm{hrs}$. The hot solution was poured onto crushed ice the formed acetate was filtered off and washed with water and dried afforded 10 as a white crystal yield $69 \%$, m.p. $200-201^{\circ} \mathrm{C}$. The IR (KBr): 3159 $(\mathrm{CH})$ aromatic bonds, $2990(\mathrm{CH})$ aliphatic bonds, 2236 $(\mathrm{C} \equiv \mathrm{N})$ groups, $1720(\mathrm{C}=\mathrm{O})$ ester, $1650(\mathrm{C}=\mathrm{O})$ amide and $1600,1523, \quad 1500,1410 \mathrm{~cm}^{-1} \quad(\mathrm{C}=\mathrm{N})$ and $(\mathrm{C}=\mathrm{C}) . \mathrm{MS}$ (m/z \%):562 ( 8\%), 561(34\% ), 501( 16\% ), 459 ( 42\% ), 441 $(16 \%), 428$ ( $13 \%), 386$ ( $12 \%)$, Anal. Calcd for: $\left(\mathrm{C}_{27} \mathrm{H}_{23} \mathrm{~N}_{5} \mathrm{O}_{9}\right.$, Mwt. 561.50): C, 57.75; H, 4.13; N, 12.47 . Found: C, 57.69; H, 4.10; N, 12.43 .

\subsubsection{0.}

3-(D-arabino-tetritol-1-yl)-6-oxo-8-(1,3-diphenyl-1Hpyrazol-4-yl)-6H-pyrido[1,2-b][1,2,4]triazine-7,9-dic arbonitrile (11):

Pyridone 3b (1 mmol, $0.393 \mathrm{~g}$ ) was added to aqueous acetic acid ( $25 \mathrm{ml}, 20 \%$ solution) and the mixture solution was stirred for 30 minutes. D-fructose $(1 \mathrm{mmol}, 0.180 \mathrm{~g}$ ) was added portion wise over 20 minutes then the mixture was heated to $100^{\circ} \mathrm{C}$ and stirred for 18 hours in a sealed flask. The reaction mixture was cooled to $10^{\circ} \mathrm{C}$ for 5 hours, the precipitate filtered off and washed with water and dried gave 11 as a whitish green powder,yield $46 \%$, m.p. $280-281^{\circ} \mathrm{C}$. MS (m/z \%): 535 (26\%), 517 (11\%), 504 (17\%), 474 (29\%), 457 (22\%), 456 (15\%), 444 (100\%), 443 (51\%), 442 (15\%), 414 (14\%), 387 (25\%), 361 (53\%). Anal. Calcd for: $\left(\mathrm{C}_{28} \mathrm{H}_{21} \mathrm{~N}_{7} \mathrm{O}_{5}\right.$, M.W. 535.51): C, 62.80; H, 3.95; N, 18.31 . Found: C, 62.83; H, 3.98; N, 18.34 .

\section{Result and Discussion}

2-Amino substituted $\mathrm{N}$-aminopyridones $3 \mathrm{a}$, b can be obtained by Michael addition of cyanoacetohydrazide (1) to arylidinemalononitrile $2 \mathrm{a}$ or $2 \mathrm{~b}$ [10].

The ${ }^{1} \mathrm{H}-\mathrm{NMR}$ spectrum of $3 \mathrm{a}$ in DMSO- $\mathrm{d}_{6}$ exhibited signals at $\delta 5.66$ for $\mathrm{NH}_{2}$, and 8.48 for $\mathrm{NH}_{2} \mathrm{ppm}$. Also, the ${ }^{1} \mathrm{H}-\mathrm{NMR}$ spectrum of $3 \mathrm{~b}$ in $\mathrm{CDCl}_{3}$ showed signals at $\delta 4.70$ for $\mathrm{NH}_{2}$ ppm. Diverse biological activities encountered in fused heterocyclic system containing pyridine [11], triazole [12] and 1,2,4-triazole [12]. From that view, it was interested to study the condensation reaction of (3a) with D-glucose or/and D-xylose in the presence of methanolic iodine and diluted acetic acid at room temperature with stirring for 24 hours afforded compound 4 or/and 5 compounds respectively.<smiles>N#CCC(=O)NN</smiles>

1<smiles>[X]C=C(C#N)C#N</smiles>

$2 a, b$

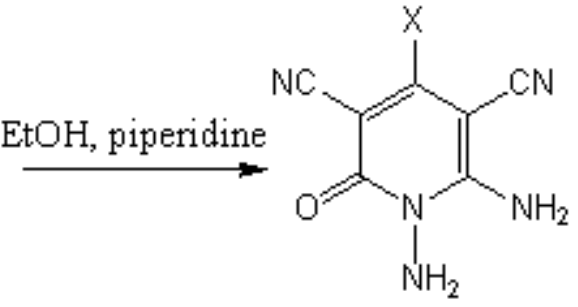

3a, b

$\mathrm{a} ; \mathrm{x}=$ phenyl<smiles>Cc1cn(-c2ccccc2)nc1-c1ccccc1</smiles>

Figure 1. Synthesis of N-aminopyridones 


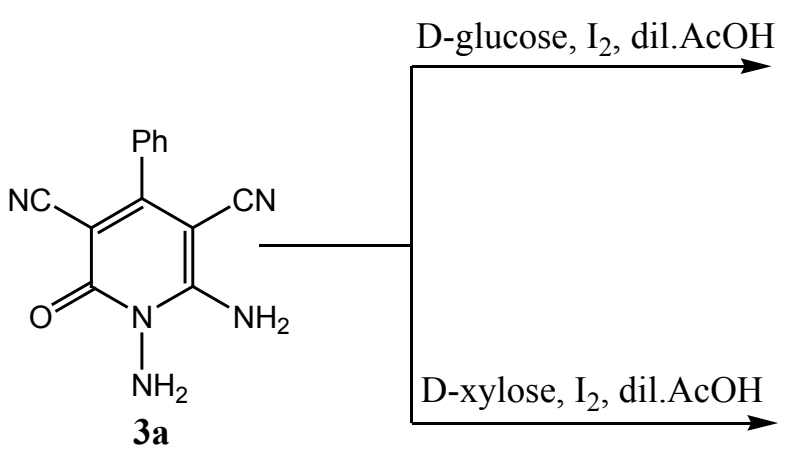<smiles>N#Cc1c(-c2ccccc2)c(C#N)c2nc(COCCO)[nH]n2c1=O</smiles><smiles>N#Cc1c(-c2ccccc2)c(C#N)c2nc(C(O)CO)[nH]n2c1=O</smiles>

Figure 2. Synthesis of compounds 4 and 5<smiles>[X]c1c(C#N)c(N)n(N)c(=O)c1C#N</smiles>

\section{D-xylose, $\mathrm{I}_{2} \mathrm{AcOH}, \mathrm{DMF}$ $50^{\circ} \mathrm{C}$}

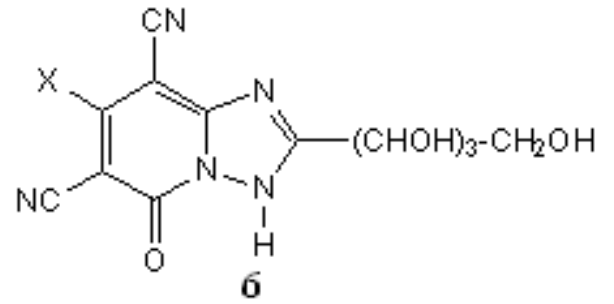

3b<smiles>[X]#Cc1nn(-c2ccccc2)cc1C</smiles>

Figure 3. Coupling compound $3 b$ with D-xylose

The chemical structure of compounds 4 and 5 were confirmed by elemental analysis and spectral data. The I.R. spectrum of 4 showed absorption bands at $3395 \mathrm{~cm}^{-1}$ due to $(\mathrm{OH})$ groups, $3236 \mathrm{~cm}^{-1}$ due to $(\mathrm{NH})$ group, $3195 \mathrm{~cm}^{-1}$ due to (CH) aromatic bonds, $2949 \mathrm{~cm}^{-1}$ due to $(\mathrm{CH})$ aliphatic bonds, $2236 \mathrm{~cm}^{-1}$ due to $(\mathrm{C} \equiv \mathrm{N})$ groups and 1695 due to $(\mathrm{C}=\mathrm{O})$ amide group and $1605,1521,1465 \mathrm{~cm}^{-1}$ due to $(\mathrm{C}=\mathrm{N})$ and $(\mathrm{C}=\mathrm{C})$ groups. The mass spectrum of 4 showed molecular ion peaks at $\mathrm{m} / \mathrm{z}: 412(8 \%, \mathrm{M}+1), 411(34 \%, \mathrm{M}), 393(51 \%$, $\left.\mathrm{M}-\mathrm{H}_{2} \mathrm{O}\right), \quad 380 \quad\left(24 \%, \quad \mathrm{M}-\mathrm{CH}_{2} \mathrm{OH}\right), \quad 322 \quad(20 \%$, $\left.\mathrm{BH}_{2} \mathrm{CHOHCHOH}\right), 321$ (34\%, ВНCHOHCHOH), 320 (44\%,BCHOHCHOH), $305\left(22 \%, \mathrm{BH}_{2} \mathrm{CHCHOH}\right)$, $304(10 \%, \mathrm{BHCHCHOH}), 292\left(36 \%, \mathrm{BHCH}_{2} \mathrm{OH}\right), 290$ $(100 \%, \mathrm{BCHOH}), 275\left(13 \%, \mathrm{BCH}_{3}\right), 274\left(11 \%, \mathrm{BCH}_{2}\right)$, $261(11 \%, \mathrm{BH}), 260(42 \%, \mathrm{~B}), 234(34 \%, \mathrm{~B}-\mathrm{CN})$ and $77(50 \%, \mathrm{ph})$. Where $(\mathrm{B})=$ Heterobase moiety.

The I.R. spectrum of 5 showed absorption bands at 3400 $\mathrm{cm}^{-1}$ due to $(\mathrm{OH})$ groups, $3232 \mathrm{~cm}^{-1}$ due to $(\mathrm{NH})$ group, 3193 $\mathrm{cm}^{-1}$ due to $(\mathrm{CH})$ aromatic bonds, $2925 \mathrm{~cm}^{-1}$ due to $(\mathrm{CH})$ aliphatic bonds, $2225 \mathrm{~cm}^{-1}$ due to $(\mathrm{C} \equiv \mathrm{N})$ groups and 1672 due to $(\mathrm{C}=\mathrm{O})$ amide group and $1593,1539,1427 \mathrm{~cm}^{-1}$ due to $(\mathrm{C}=\mathrm{N})$ and $(\mathrm{C}=\mathrm{C})$ groups. The mass spectrum of 5 showed molecular ion peaks at m/z: 382(13\%, M+1), $381(28 \%, \mathrm{M})$, $364(24 \%, \mathrm{M}-\mathrm{OH}), 350\left(13 \%, \mathrm{M}-\mathrm{CH}_{2} \mathrm{OH}\right), 322(17 \%, \mathrm{BH}$ $\left.\mathrm{CH}_{2} \mathrm{OHCHOH}\right), 321(10 \%$, BHCHOHCHOH $), 320(27 \%$, $\mathrm{BCHOHCHOH}), 303$ (1 9\%, BCHCHOH), 302 (13\%, BCHCHO), $291\left(65, \mathrm{BHCH}_{2} \mathrm{OH}\right), 289(17 \%, \mathrm{BCHO}), 288$ (6\%, BCO), $275\left(24 \%, \mathrm{BCH}_{3}\right), 261(17 \%, \mathrm{BH}), 260(34 \%$, $\mathrm{B}), 234(20 \%, \mathrm{~B}-\mathrm{CN})$ and $77(100 \%, \mathrm{ph})$, where $\mathrm{B}=$ heterocycle base.

Condensation pyridone $3 \mathrm{~b}$ with D-xylose in a mixture of dimethyl formamide, diluted acetic acid and iodine solution with slight heating at $50^{\circ} \mathrm{c}$ and stirring for 10 hours gave triazolopyridone derivative (6).

The chemical structure of 6 was confirmed by elemental analysis and spectral data. The I.R. spectrum data of compound 6 showed absorption bands at $3400 \mathrm{~cm}^{-1}$ due to $(\mathrm{OH})$ groups, $3150 \mathrm{~cm}^{-1}$ due to $(\mathrm{NH})$ group, $3000 \mathrm{~cm}^{-1}$ due to (CH) aromatic bands , $2925 \mathrm{~cm}^{-1}$ due to $(\mathrm{CH})$ aliphatic bands, $2236 \mathrm{~cm}^{-1}$ due to $(\mathrm{C} \equiv \mathrm{N})$ groups and 1666 due to $(\mathrm{C}=\mathrm{O})$ 
amide group and $1600,1593,1504,1410 \mathrm{~cm}^{-1}$ due to $(\mathrm{C}=\mathrm{N})$ and $(\mathrm{C}=\mathrm{C})$ groups. The mass spectrum of 6 showed molecular ion peaks at m/z: $523(34 \%, \mathrm{M}), 492(10 \%$, $\left.\mathrm{M}-\mathrm{CH}_{2} \mathrm{OH}\right), 464\left(60 \%, \mathrm{BH}_{2} \mathrm{CHOHCHOH}\right), 463(76 \%$, $\mathrm{BHCHOHCHOH}), 462(50 \%$, BCHOHCHOH $), 447$ (11\%, $\left.\mathrm{BH}_{2} \mathrm{CHCHOH}\right), 446(13 \%$, $\mathrm{BHCHCHOH}) 445(52 \%$, $\mathrm{BCHCHOH}), 433\left(100 \%, \mathrm{BCH}_{2} \mathrm{OH}\right), 432(12 \%, \mathrm{BCHO})$, 431 (13\%,BCHO), 430 (36\%, BCO), 402 (10\%, B), $376(9 \%$, BH-HCN), 375 (45 \%, B-HCN), where (B)=heterobase moiety.

Compound 4 was heated with acetic anhydride under reflux for three hours, then poured onto crushed ice afforded acetylated compound 7 .

The chemical composition of 7 was confirmed by elemental analysis, I.R and the mass spectrum.

The I.R. spectrum of compound 7 showed no absorption band for $(\mathrm{OH})$ groups and appeared absorption bands at 3059 $\mathrm{cm}^{-1}$ due to $(\mathrm{CH})$ aromatic bonds, $2920 \mathrm{~cm}^{-1}$ due to $(\mathrm{CH})$ aliphatic bonds, $2223 \mathrm{~cm}^{-1}$ due to $(\mathrm{C} \equiv \mathrm{N})$ groups, $1725 \mathrm{~cm}^{-1}$ due to $(\mathrm{C}=\mathrm{O})$ ester, $1678(\mathrm{C}=\mathrm{O})$ amide and 1596,1530 , $1503,1432 \mathrm{~cm}^{-1}$ due to $(\mathrm{C}=\mathrm{N})$ and $(\mathrm{C}=\mathrm{C})$.

the mass fragmention showed ion peaks at $\mathrm{m} / \mathrm{z}: 663$ $(56 \%, \mathrm{M}), 620\left(38 \%, \mathrm{CH}_{3} \mathrm{CO}\right), 603(12 \%, \mathrm{M}-\mathrm{AcOH}), 561$ $(28 \%$, M-AcOH-CH$-\mathrm{CO}), 549\left(12 \%, 561-\mathrm{AcOH}-\mathrm{CH}_{2} \mathrm{CO}\right)$, $543(12 \%, \mathrm{M}-2 \mathrm{AcOH}), 530\left(28 \%, \mathrm{M}-\mathrm{AcOH}-\mathrm{CH}_{2} \mathrm{OAc}\right), 501$
(16\%,561-AcOH), $488\left(29 \%, 530-\mathrm{CH}_{2} \mathrm{CO}\right), 387(17 \%$, $\left.\mathrm{BC}_{2} \mathrm{H}_{2} \mathrm{OAc}\right), \quad 362 \quad(16 \% \quad$,BHOAc $), 345 \quad(41 \%$, $\left.\mathrm{BCH}_{2} \mathrm{CHO}\right), 332(100 \%, \mathrm{BCHOH}), 316\left(12 \%, \mathrm{BCH}_{2}\right), 302$ (28\%,B), 275 (30\%, B-HCN), 259 (12\%,B-Ac), 246 (36\%), $219(12 \%), 127(36 \%), 77(66 \%), 50(55 \%)$, where $(\mathrm{B})=$ heterobase moiety.

Similarly, compound 5 was boiled with acetic anhydride as the previous conditions obtained 8 .

The chemical composition of 8 was confirmed by elemental analysis and the mass spectrum.

The mass fragmention of 8 showed ion peaks at $\mathrm{m} / \mathrm{z}: 591$ $(33 \%, \mathrm{M}), 531(13 \%, \mathrm{M}-\mathrm{AcOH}), 489\left(29 \%, \mathrm{M}-\mathrm{AcOH}-\mathrm{CH}_{2} \mathrm{CO}\right)$, $471(25 \%, \mathrm{M}-2 \mathrm{AcOH}), 458\left(13 \%, \mathrm{M}-\mathrm{AcOH}-\mathrm{CH}_{2} \mathrm{OAc}\right)$, $429(9 \%, 489-\mathrm{AcOH}), 416\left(10 \%, 458-\mathrm{CH}_{2} \mathrm{CO}\right)$, 387 ( $7 \%$, B CHCHOAc), $345 \%$, $\left.\mathrm{BCH}_{2} \mathrm{CHO}\right)$, $332(76 \%, \mathrm{BCHOH}), \quad 330(30 \%, \mathrm{BCO}), \quad 316\left(8 \%, \mathrm{BCH}_{2}\right)$, $302(13 \%, \mathrm{~B}), \quad 276(37 \%, \mathrm{~B}-\mathrm{HCN}), \quad 259(16 \%), 219$ (9\%), $127(19 \%), 77(100 \%)$ where $(\mathrm{B})=$ heterobase moiety.

Heating compound 3a with D-fructose and few drops of conc. hydrochloric acid in ethanol with reflux in a sealed flask for 5 hours gave compound 9 [13], which acetylated with acetic anhydride in the presence of pyridine for 24 hours at room temperature gave compound 10 .<smiles>N#Cc1c(-c2ccccc2)c(C#N)c2nc(CO)[nH]n2c1=O</smiles><smiles>CC(=O)OCCOCc1nc2c(C#N)c(-c3ccccc3)c(C#N)c(=O)n2n1[Te]</smiles>

Figure 4. Acetylating of compound 4<smiles>N#Cc1c(-c2ccccc2)c(C#N)c2nc(C(O)CO)[nH]n2c1=O</smiles><smiles>CC(=O)OCOC(C)OCc1nc2c(C#N)c(-c3ccccc3)c(C#N)c(=O)n2n1C#N</smiles>

Figure 5. Acetylating of compound 5 
<smiles>N#Cc1c(-c2ccccc2)c(C#N)c(=O)n(N)c1N</smiles>

3a<smiles>N#Cc1c(-c2ccccc2)c(C#N)c2ncc(C(CO)OCO)nn2c1=O</smiles>

(ii)

reactin condition:

(i) D-Fructose, Conc. $\mathrm{HCl}$,ethanol,reflux $5 \mathrm{hr}$.

(ii) $\mathrm{Ac}_{2} \mathrm{O}$, pyridine, rt.

10

Figure 6. Synthesis of compounds 9 and 10<smiles>[X]c1c(C#N)c(N)n(N)c(=O)c1C#N</smiles>

3b<smiles></smiles>

reactin condition:

(i) D-fructose, aq.AcOH, heat, $18 \mathrm{hr}$. (i)<smiles>[X]c1c(C#N)c(=O)n2nc(CO)cnc2c1CO</smiles>

11

Figure7. Synthesis of compound 11

The chemical structure of compound 9 was confirmed by elemental analysis and the mass spectra. The mass spectrum of compound 9 showed ion peaks at m/z: $394(4 \%, \mathrm{M}+1)$, 363 (21\%, M-CHOH), 315(16\%, BCHCHOH), 314 (39\%, ВCHCHO), 303 (19\%, ВНCHOH), $302(100 \%, \mathrm{BCHOH})$, $301(20 \%$, BCHO), 300 (27\%, BCO), 272 (43\%, B), $245(47 \%$, B-HCN), 219(21\%, B-HCN-CN), where $(\mathrm{B})=$ Heterobase moiety.

The chemical structure of compound $\mathbf{1 0}$ was confirmed by elemental analysis, I.R and the mass spectra. The I.R. spectrum of compound $\mathbf{1 0}$ showed no absorption band for
$(\mathrm{OH})$ groups and appeared absorption bands at $3159 \mathrm{~cm}^{-1}$ due to $(\mathrm{CH})$ aromatic bonds, $2990 \mathrm{~cm}^{-1}$ due to $(\mathrm{CH})$ aliphatic bonds, $2236 \mathrm{~cm}^{-1}$ due to $(\mathrm{C} \equiv \mathrm{N})$ groups, $1720 \mathrm{~cm}^{-1}$ due to $(\mathrm{C}=\mathrm{O})$ ester, $1650(\mathrm{C}=\mathrm{O})$ amide and $1600,1523,1500,1410$ $\mathrm{cm}^{-1}$ due to $(\mathrm{C}=\mathrm{N})$ and $(\mathrm{C}=\mathrm{C})$. The mass spectrum of compound 10 showed ion peaks at m/z: $562(8 \%, \mathrm{M}+1)$, 561( 34\%, M ), 501( 16\%, M-AcOH ), 459 ( $42 \%$, $\left.\mathrm{M}-\mathrm{AcOH}-\mathrm{CH}_{2} \mathrm{CO}\right), 441$ (16\%, M- 2AcOH ), 428 ( $13 \%$, M - $\mathrm{AcOH}-\mathrm{CH}_{2} \mathrm{OAc}$ ), $386\left(12 \%, 428-\mathrm{CH}_{2} \mathrm{CO}\right), 382(41 \%, \mathrm{M}$ $-\mathrm{AcOH}-\mathrm{CH}_{2} \mathrm{CO}-\mathrm{AcOH}$ ), 357 ( 33\%, M- CHOAc$\mathrm{CH}_{2} \mathrm{OAc}-\mathrm{AcO}$ ), 344( 9\%,BCHOAc), 340( $19 \%, 382-\mathrm{CH}_{2} \mathrm{C}$ 
O), $\quad 327\left(\quad 9 \%, \mathrm{BCH}_{2} \mathrm{CHO}\right), \quad 302(\quad 13 \%, \mathrm{BCHOH})$, 301( 58\%,BCHO), $298\left(20 \%, \mathrm{BCH}_{2}\right), 245$ ( $\left.36 \%\right), 219$ ( $22 \%)$ and $72(100 \%)$.

A solution of D-fructose in aqueous acetic acid was heated with compound $3 \mathrm{~b}$ in a sealed flask at $100^{\circ} \mathrm{C}$ for 18 hours gave pyridotriazine derivative 11 .

The chemical structure of compound 11 was confirmed by elemental analysis and the mass spectra. The mass spectrumof compound $\mathbf{1 1}$ showed ion peaks at $\mathrm{m} / \mathrm{z}$ :

$535(26 \%, \mathrm{M}), 517\left(11 \%, \mathrm{M}-\mathrm{H}_{2} \mathrm{O}\right), 504\left(17 \%, \mathrm{M}-\mathrm{CH}_{2} \mathrm{OH}\right)$, $474(29 \%, \mathrm{BCHOHCHOH}), 457(22 \%, \mathrm{BCHCHOH}), 456$ (15\%, BCHCHO), $444(100 \%, \mathrm{BCHOH}), 443(51 \%, \mathrm{BCHO})$, 442 (15\%, BCO), 414 (14\%, B), 387 ( 25\%, B-HCN), 361 ( $53 \%, \mathrm{~B}-\mathrm{HCN}-\mathrm{CN})$.

\section{REFERENCES}

[1] W. Kobertz, C. Bertozzi , M. Rednarski, J. Org. Chem., 61, 1894, (1996)

[2] S. Macdonald, W. Huizing, T. Mckenzie, J. Org. Chem., 53,
$3371,(1988)$

[3] M. Postema, D.Calimente, L.Liu T. Behrmann, J. Org. Chem. $65,6061,(2000)$

[4] J. Jadav, B. Reddy, J. Raman, N. Niranjan S. Kumar, Tetrahedron Lett., 43, 2095, (2002)

[5] J. Beaau, T. Gallager, Top Curr. Chem., 1187, 1, (1997)

[6] Y. Ichikawa, M. Isobe, M. Konobe, T. Goto, Carboh. Res., 17, 193, (1987)

[7] G. Tolstikov, N. Prokhorova , A.Spivak, Zh.Org. Kim., 27, 2101, (1991).

[8] D. Mukherjee, P.Ray and Chowdhury U., Tetrahedron, , 57, 7701, (2001).

[9] R. Schmit, M. Hoffmann. Angew. Chem., 56, 5466, (1991)

[10] H.M.Al-Matar, K.D Khalil, H. Meier, H.Kolshorn, M.H Elnagdi. ARKIVOC 16, 288-301, (2008)

[11] K.Anand, K. Naresh. Indian. j. Hetero. chem., 3, 277, (1994)

[12] Z. El-Gendy, J. Morsy, H..Allimony and Abdel-Rahman R., J. Pharmazie, 56, 376, (2001)

[13] Aruther E. Harms; Molecular Res.; 12203, (2004) 